\title{
Początek i koniec według Pawła Beręsewicza
}

The beginning and the end according to Paweł Beręsewicz

Abstract: The article discusses and analyzes two short stories written by Paweł Beręsewicz, Kloss and Pięć niedźwiedzi (Five bears), contained in a short story collection entitled Ściśle tajne (Top secret). The considerations pertain to death and the beginning of human life, the author's philosophy. The said two short stories decisively have educational and cognitive value; they can serve as a stimulus to discuss existential topics with children.

Keywords: Paweł Beręsewicz, life, death, children's book, philosophy

Stary proboszcz komentował niedzielną Ewangelię, dodając do tekstu trzy słowa ${ }^{1}$. Posłużę się tą metodą, analizując dwa opowiadania Pawła Beręsewicza Kloss i Pięć niedźwiedzi zebrane w tomie pod wspólnym tytułem Ściśle tajne (Beręsewicz, 2018). Książka była nominowana w 2019 roku do Ogólnopolskiej Nagrody Literackiej im. Kornela Makuszyńskiego.

Trzy słowa, które, moim zdaniem, charakteryzują wymienione teksty to: pamięć, tożsamość i tajemnica (miłość). Zapewne nie są to jedyne słowa, jakimi można podsumować przywołane w tekście dwa opowiadania Beręsewicza.

Autor, w charakterystyczny dla siebie, przewrotny sposób, próbuje znaleźć odpowiedzi na odwieczne pytania o to, co działo się z człowiekiem przed urodzeniem, i o tym, co dzieje się z nim po śmierci.

Wokół początku życia ludzkiego

Narodziny wcale nie są początkiem życia, są jedynie jego przejściem na nowy, trudniejszy etap. Pytania o początki życia, o jego powstanie zarówno w skali glo-

${ }^{1}$ Podobno była to metoda, którą się posługiwał ksiądz Jan Twardowski, ale nie znalazłam potwierdzenia tej informacji. 
balnej całego świata, jak i w skali mikro - pojedynczego człowieka, fascynowały i fascynują nadal wielu. Przeświadczenie, że życie człowieka zaczyna się od poczęcia, z chwilą połączenia dwóch komórek, kazało dodawać starożytnym Chińczykom dziewięć miesięcy do wieku człowieka. Współczesne badania psychologii prenatalnej wykazują, że dziecko przed urodzeniem słyszy, rozumie i zapamiętuje kierowane do niego informacje. Najważniejszą z nich jest oczywiście miłość (Nitecka, Staszewska, Piertkiewicz-Rok, 1987).

Natomiast według żydowskiej legendy każda ludzka dusza, zanim się człowiek urodzi, jest w raju. I tam przeżywa swoje rajskie życie. W chwili gdy ma przyjść na świat w ludzkim ciele, dostaje od anioła prztyczka w nos. Prztyczek w nos odbiera duszy pamięć o raju. Pisał o tym m.in. Icyk Manger w znakomitej powieści Księga raju... (Manger, 1988, s. 199).

Prztyczek w nos może tłumaczyć, dlaczego nie pamiętamy czasu sprzed narodzin. Ale nie wie o tym bohater opowiadania Pięć niedźwiedzi, jak siebie sam określa - starszy brat, który planuje swoisty eksperyment właśnie pod takim kryptonimem. Eksperyment polega na czytaniu przez pięć miesięcy po jednej zwrotce wiersza nienarodzonemu jeszcze bratu. Chłopiec liczy na to, że ukryty w brzuchu mamy maluch zapamięta czytaną treść. To zupełnie odwrotna sytuacja niż ta, z którą spotyka się czytelnik książki Anny Janko o nienarodzonych jeszcze bliźniakach, które toczą z sobą rozmowy w brzuchu mamy i zastanawiają się, jak wygląda świat na zewnątrz, a przede wszystkim jak wygląda mama (Janko, 2012, s. 64).

Według chłopca, pamięć jest znakiem bycia, człowiek to pamięć, wcześniejsze doświadczenia są zamknięte w mózgu na hasło. Pytanie: byłem czy nie byłem? - gdybym był, przecież bym pamiętał, zaprząta głowę chłopca. Sam sobie stawia pytania: ,[...] jak wyglądało niebo widziane z wózka, kto mnie nauczył chodzić, czy mleko mamy było smaczne, kiedy przyszła mi do głowy pierwsza myśl” (Beręsewicz, 2018, s. 32). Czytając, chce w ten sposób „Zabezpieczyć wspomnienia" małego brata:

[...] miał już pewnie główkę, nóżki i serce. Może już nawet coś myślał, coś słyszał, coś czuł - tak jak ja wtedy w Paryżu, czego przez zablokowaną klapkę zupełnie nie pamiętałem. Na moją pamięć nie dało się już, niestety, nic poradzić, ale może można by coś zrobić, żeby u tego małego brata zabezpieczyć wspomnienia.

Beręsewicz, 2018, s. 35

Beręsewicz w przewrotny sposób nie daje odpowiedzi na pytanie o powodzenie eksperymentu - rodzą się bliźniaki, o czym bohater nie wiedział. I prawdopodobnie dlatego, ku rozpaczy starszego brata, zajęte sobą maluchy nic nie pamiętają z głośnego czytania. 
Wokół końca życia ludzkiego

Znacznie bardziej rozbudowany jest wątek końca życia ludzkiego i tego, co następuje po śmierci. W opowiadaniu Kloss Beręsewicza śmierć jest poprzedzona starością - z wiekiem człowiek staje się niższy, słabo chodzi, wszystko robi wolno. Ale ważną cechą osoby starszej jest umiejętność opowiadania, wspominania tego, co było, i to w taki sposób, że opowiadacz zdoła zainteresować innych. $\mathrm{W}$ tym miejscu warto przywołać, również nominowaną w tym samym konkursie, książkę Anny Janko Oleś i pani Róża (Janko, 2018) ze znakomitym portretem starego, umierającego dziadka i uważnie słuchającej jego opowieści wnuczki. Oba utwory, Beręsewicza i Janko, mają wspólny mianownik.

W opowiadaniu Kloss śmierć jest wyrażona przez cmentarz, grób, pomnik z wyrytym imieniem, nazwiskiem oraz klamrą dat życia i śmierci. Zmarłych tradycyjnie odwiedza się w dzień Wszystkich Świętych, 1 listopada, z chryzantemą i ze zniczem i, co ważne, jest to rodzinna wyprawa. Dla dziecka dzień to niezwykły także z innego powodu - jedyny w roku, kiedy wolno mu wziąć do ręki zapałki.

Warstwę słowną dopełniają znakomite ilustracje Macieja Szymanowicza. Szczególnie kapitalny jest obraz cmentarza uzupełniony strzępkami, jak tego chce Beręsewicz, rozmów: „Tu leży stryj, pamiętasz stryja? Miał taką śmieszną muszkę zwykle i ciągle mówił: Mamma mia!, a raz was przewiózł motocyklem” czy „A tutaj żona brata zięcia kuzynki męża ciotki Ady, ta od tej willi z tego zdjęcia, z tego albumu, z tej szuflady" (Beręsewicz, 2018, s. 16-17). Takie właśnie rozmowy/obrazy pamięci są chyba doświadczeniem wielu $z$ nas, podobnie jak sama droga przez cmentarz, aby odnaleźć groby bliskich:

Ludzie wspominali, rozmawiali, zapalali znicze, a my szliśmy krętą drogą, której nikt poza nami nie potrafiłby zapamiętać. Najpierw prosto, potem w lewo, w prawo, znów kawałek prosto, w lewo, w prawo, w lewo, w prawo, prosto, prosto, przy grubym klonie jeszcze raz w prawo i już.

Beręsewicz, 2018, s. 19

O śmierci mówi się cicho. Nie ma wątpliwości, że później jest niebo, tam się odchodzi, gdy jest się bardzo starym, tam przebywa Mała Babcia, której bohater nie zdążył poznać. Beręsewicz przekazuje chrześcijańską wiarę w obcowanie świętych - zmarli przychodzą we śnie. Zmarła Mała Babcia we śnie jest taka sama, jak za życia - celnie pluje pestką z wiśni, choć to zachowanie raczej przystoi dzieciom niż dorosłym, jest młoda ciałem i duchem. Zmarli zawsze zostają w naszej pamięci jako najlepsi, pamiętamy ich najlepsze cechy, chwile spędzone razem. To stara zasada, że o zmarłych mówi się dobrze albo wcale.

Beręsewicz nie pyta o śmierć i jej istotę. Dla niego oraz jego bohaterów jest ona oczywista, znacznie bardziej interesujące jest to, co dzieje się po śmierci. Niepewność i pytanie budzi to, co jest w niebie i czym można się tam zajmować. 
To pytanie staje się podstawą tajnej misji zleconej przez dziadka wnukowi. Podczas wizyty na cmentarzu chłopiec ma odebrać meldunek od Małej Babci, ma sprawdzić, czy na grobie będzie leżał listek z drzewa - jeśli tak, to znak, że w niebie są ciągutki. Tu autor nie daje jednoznacznej odpowiedzi. Na grobie leży nie jeden, lecz cała sterta liści. Zatem nie wiemy do końca, czy w niebie są ciągutki, choć jak mówi dziadek, jest niebieski sklepik. To oczywiste, że ludzka wyobraźnia, wiedza nie sięgają dalej niż to, co widzimy i słyszymy tu na ziemi. Jak mówi apostoł w swoim liście, „ani oko nie widziało, ani ucho nie słyszało, ani serce człowieka nie zdołało pojąć, jak wielkie rzeczy Bóg przygotował tym, którzy Go miłują" (1 Kor 2,9, Biblia Tysiąclecia).

Przypomina się w tym miejscu dziecięca piosenka: „Niebo to najwspanialsze z miejsc, łaska, chwała czeka tam cię, Boga twarz zobaczysz też, niebo najwspanialsze z miejsc - mówię wam to". Twarzy Boga nie widzimy w utworze Beręsewicza, ale niebo rzeczywiście jawi się jako wspaniałe miejsce, choć pozostaje kolejne pytanie: czy nie jest w nim nudno...?

Ta sprawa interesuje wnuka, który chce wiedzieć, czy w niebie będzie można grać w piłkę nożną i co się będzie działo, gdy nie będzie przegranych; przecież w niebie wszystkim ma być fajnie. Chłopiec umawia się z dziadkiem na meldunek. I tym razem jednak jest on nieprecyzyjny. Kurek na kościelnej wieży obraca się raz w jedną, raz w drugą stronę. I ponownie nie dowiadujemy się, jak jest w niebie. Zatem tajemnica nieba pozostaje, mimo wysiłków bohatera, tajemnicą. „Tajemnica świata, stosunków między ludźmi, tajemnica przemijania, miłości, starości, śmierci [...]. Każda rzecz na świecie ma swoją tajemnicę. Chodzi tylko o to, żeby ją dostrzec i wydobyć. I tym właśnie zajmuje się poezja" (Danuta Wawiłow; cyt. za: Kulka, 1994, s. 258).

Podążając za słowami Danuty Wawiłow, autor okazuje się nie tylko poetą, ale i filozofem, nade wszystko zaś człowiekiem wiary. Beręsewicz, pisząc o życiu i śmierci, nie kłamie. Jego koncepcja człowieka, wizja świata nie są fałszywe. To wizja na wskroś chrześcijańska, która opiera się na wierze. Życie i śmierć są tajemnicą, z którą człowiek próbuje się uporać od początku swojego istnienia. Skąd przychodzimy i dokąd zmierzamy - oto odwieczne pytania człowieka. Odpowiedź na nie daje właśnie wiara.

Tożsamość jednostki w stosunku do samej siebie (selfidentity), jak również do innych, przede wszystkim rodziny, jest budowana m.in. na pamięci o bliższych i dalszych zmarłych (świetne opowiadanie o mnożeniu pradziadów - Beręsewicz, 2007, s. 165-171). Wiemy, kim jesteśmy. Naszą tożsamość budują też zgromadzone na strychu, w Muzeum Historii Ciumków, rzeczy (Beręsewicz, 2007, s. 5-11). Te, do których byliśmy mocno przywiązani, a które uległy zniszczeniu.

Niebo istnieje wszak nie tylko dla ludzi, również dla rowerów:

Po starym wysłużonym przyjacielu zostały wspomnienia i ta ostatnia fotografia, na którą czasem kapią łzy. Ale nie martw się o niego, Drogi Czytelniku. 
Pewnie przemierza właśnie równe jak stół asfalty rowerowego raju. Tam nigdy nie rdzewieją łańcuchy, szkło z rozbitych butelek nie kaleczy opon, a kiedy się tylko zapragnie, skrzydlaci mechanicy czule smarują ci piasty.

Beręsewicz, 2010, s. 153

Ale co ciekawe, do psiego raju nie idzie Burek, ukochany pies Ciumków, po którym też zostaje wdzięczna i ciepła pamięć, utrwalona plamą na ścianie (Beręsewicz, 2007, s. 78-85).

W świecie dziecka sekret, tajemnica mają szczególne miejsce, budzą emocje, jakich już rzadko doświadczają dorośli. Jednym ze sposobów sugerowania tego, co nieznane, zakryte, niewypowiedziane, jest pytanie - ulubiony sposób zachowań językowych małego dziecka.

Zabawa, 2013, s. 119

Opowieści Beręsewicza są proste, pytania zadawane wprost, doświadczenie zdobywane w rozmowie. Towarzyszą im pogodny nastrój i nieodłączny humor autora. Tak wygląda początek i koniec życia według Pawła Beręsewicza. Pomiędzy nimi są m.in. pierwsza spowiedź, jedyny sakrament, o którym pisze autor, wędrówki w góry oraz wspólne rodzinne wyprawy, nade wszystko tożsamość budowana na pamięci i łącząca je miłość.

\section{Literatura}

Beręsewicz P., 2007, Ciumkowe historie, w tym jedna smutna, Kraków.

Beręsewicz P., 2010, Ciumkowie w szkocką kratę, Kraków.

Beręsewicz P., 2018, Ściśle tajne, Łódź.

Janko A., 2012, Maciupek i Maleńtas. Niezwykłe przygody w Brzuchu Mamy, Warszawa. Janko A., 2018, Oleś i pani Róża, Kraków.

Kulka B., 1994, Świat dziecięcych doznań w poezji Danuty Wawiłow, w: Chęcińska U., red., Dziecko i jego światy w poezji dla dzieci, Szczecin, s. 194-205.

Manger I., 1988, Księga raju, czyli przedziwne żywota opisanie Szmula Aby Aberwo, Warszawa.

Nitecka E., Staszewska D., Pietkiewicz-Rok E., 1987, Miłość od poczęcia, Warszawa.

Zabawa K., 2013, Rozpoczęta opowieść. Polska literatura dziecięca po 1989 roku wobec kultury współczesnej, Kraków.

Grażyna Lewandowicz-Nosal - doktor nauk humanistycznych, specjalista w zakresie bibliotek publicznych dla dzieci, literatury dla dzieci i młodzieży. Członek PS IBBY, kolegium redakcyjnego „Guliwera. Czasopisma o Książce dla Dziecka” i „Poradnika Bibliotekarza”. Juror ogólnopolskiej Nagrody Literackiej im. Kornela Makuszyńskiego. Główne publikacje to: Adaptacje Biblii dla dzieci w Polsce w XX wieku. Biblio- 
grafia (Warszawa 2003); Biblioteki publiczne dla dzieci. Wczoraj i dziś. Poradnik (Warszawa 2008); Dzieci, młodzież - Internet - biblioteka. Wytyczne IFLA Sekcji Bibliotek dla Dzieci i Młodzieży (Warszawa 2009); Biblioteki publiczne dla dzieci w Polsce. Raport $z$ badań (Warszawa 2013); Warto mieć w bibliotece. Książki dla dzieci 2010-2014. Kata$\log$ (Warszawa 2015).

e-mail: grazyna.lewandowicz@poczta.onet.pl 